\title{
Functional and Clinical Results of Patients Who Underwent an Ileal Pouch-anal Anastomosis
}

\section{İleal Poş-anal Anastomoz Yapılan Hastaların Fonksiyonel ve Klinik Sonuçları}

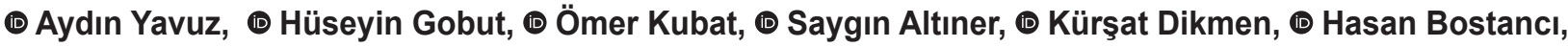 \\ (1) Osman Yüksel
}

Gazi University Faculty of Medicine, Deparment of General Surgery, Ankara, Turkey

\section{IIIIIIII| ABSTRACT}

Aim: To evaluate the characteristics, early and late complications, outcomes, quality of life, and procedure-related problems in patients who underwent restorative proctocolectomy performed with the ileal pouch-anal anastomosis (IPAA) approach.

Method: Twenty-two of the 26 patients who underwent IPAA from 2007 to 2019 were included. Data collected included demographic characteristics, surgical indications, operation types, histopathological diagnosis, early ( $<3$ months) and late ( $\geq 3$ months) postoperative complications, and functional outcomes. The Cleveland Global Quality of Life score was used to evaluate quality of life.

Results: Ten (45.5\%) participants had ulcerative colitis (UC) and 12 (54.5\%) had familial adenomatous polyposis (FAP). Nineteen (86.4\%) patients underwent a two-stage surgical procedure. Early post-operative complications were: ileus $\mathrm{n}=4$ (18.2\%); wound infection $\mathrm{n}=4$ (18.2\%); pelvic abscess $\mathrm{n}=3(13.6 \%)$; and other complications $\mathrm{n}=5$ (22.7\%). Late complications were: pouchitis $\mathrm{n}=2$ (9.1\%); anastomotic stenosis $\mathrm{n}=2$ (9.1\%); and pouch dysfunction $\mathrm{n}=2$ (9.1\%). Additionally, six (27.3\%) reported experiencing fluid incontinence, of whom four (18.2\%) were using pads during the day, and the mean defecation frequencies were $4.3 \pm 2.4$ during the day and $1.04 \pm 0.89$ during the night. Half of the patients (50\%) had complaints of sexual dysfunction. It was noticed that 2 of the patients (9.1\%) were using antidiarrheal drugs and 1 patient (4.5\%) became pregnant 2 times after the operation. Quality of life score was significantly higher in patients with FAP $(0.85 \pm 0.13)$ compared to patients with UC $(0.71 \pm 0.11)$.

Conclusion: This procedure can be applied safely with low comorbidity and good functional outcomes in centers with high caseloads and thus sufficient experience.

Keywords: Restorative proctocolectomy, ileal pouch-anal anastomosis, ulcerative colitis, familial adenomatous polyposis

\section{|||||||||| ÖZ}

Amaç: Amacımız kliniğimizde ileal poş-anal anastomoz (IPAA) yapılan hastaların özelliklerini, erken ve geç komplikasyonlarını, hastaların hayat kalitesi gibi İPAA sonrası gelişebilecek problemler ve sonuçları değerlendirmektir.

Yöntem: Kliniğinimizde 2007 ile 2019 yılları arasında İAA yapılan 26 hastanın 22'si çalışmaya dahil edildi. Hastalara ait demografik özellikler, cerrahi endikasyonlar, operasyon tipi, patolojik tanı gibi sonuçları, erken ( $<3$ ay) ve geç ( $\geq 3$ ay) postoperatif komplikasyonları, fonksiyonel sonuçları değerlendirildi. Hayat kalitesinin değerlendirilmesi için Cleveland Global Quality of Life skorlaması uygulandı.

Bulgular: Hastaların 10’u ülseratif kolit (ÜK), 12'si ailesel adenomatöz polipozis (FAP) idi. On dokuz hastaya (\%86,4) 2 aşamalı cerrahi prosedür uygulandı. Postoperatif erken dönemde hastalarda; ileus $\mathrm{n}=4(\% 18,2)$, yara yeri enfeksiyonu $\mathrm{n}=4(\% 18,2)$, pelvik apse $\mathrm{n}=3(\% 13,6)$ ve diğer komplikasyonlar n=5 (\%22,7) idi. Geç komplikasyonlar: poşit n=2 (\%9,1), anastomoz darlığı n=2 (\%9,1), poş disfonksiyonu n=2 (\%9,1) idi. Hastaların

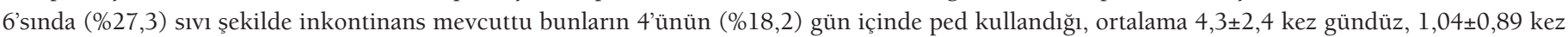
gece defekasyon ihtiyacı olduğu, yarısında (\%50) cinsel disfonksiyon şikayeti görüldü. Hastalardan 2'si (\%9,1) antidiaretik ilaç kullanmaktaydı ve 1 hastanın $(\% 4,5)$ operasyon sonrası 2 kez gebe kaldığı öğrenildi. FAP hastalarının $(0,85 \pm 0,13)$ ÜK hastalarına $(0,71 \pm 0,11)$ göre hayat kalitesi skorunun anlamlı şekilde iyi olduğu görüldü.

Sonuç: Bu prosedür, yüksek vaka yükü ve yeterli deneyime sahip merkezlerde düşük komorbidite ve iyi fonksiyonel sonuçlarla güvenle uygulanabilir. Anahtar Kelimeler: Restoratif proktokolektomi, ileal poş-anal anastomoz, ülseratif kolit, familial adenomatozis polipozis

Address for Correspondence/Yazışma Adresi: Aydın Yavuz, MD,

Gazi University Faculty of Medicine, Deparment of General Surgery, Ankara, Turkey

E-mail: aydinyavuz@yahoo.com ORCID ID: orcid.org/0000-0003-0091-7997

Received/Gelis Tarihi: 21.02.2021 Accepted/Kabul Tarihi: 14.05.2021

${ }^{\odot}$ Copyright 2021 by Turkish Society of Colon and Rectal Surgery

Turkish Journal of Colorectal Disease published by Galenos Publishing House. 


\section{Introduction}

Restorative proctocolectomy (RP) with ileal pouch-anal anastomosis (IPAA) is a procedure used to perform ileoanal anastomosis, with proven effectiveness in the surgical treatment of ulcerative colitis (UC) and familial adenomatous polyposis (FAP). ${ }^{1}$ It is well-established that this procedure can be performed with acceptable functional outcomes and high success rates in experienced hands.

$\mathrm{UC}$ is an inflammatory bowel disease affecting the colorectal mucosa that often develops in the third or eighth decades of life. Indications for surgery include unresponsiveness to medical treatment, severe bleeding, cancer risk, obstruction, perforation, and toxic megacolon. ${ }^{2}$ In contrast, FAP is an inherited, autosomal dominant disease caused by a germline mutation of the adenomatous polyposis coli gene. ${ }^{3}$ If FAP is left untreated, colorectal cancer is inevitable, and it has been demonstrated that the complete removal of the colorectal mucosa prevents development of colorectal cancer. ${ }^{4}$ Patients with UC and FAP may require RP, although the procedure may be applied in patients suffering from some other conditions.

The aim of this study was to describe our experience with IPAA by evaluating the characteristics, early and late complications, outcomes, quality of life and procedurerelated problems of patients who underwent IPAA in our center.

\section{Materials and Methods}

Following approval from the institutional Clinical Research Ethics Committee (24074710-06), a total of 26 patients who underwent IPAA at the General Surgery Department, between November 2007 and November 2019, were evaluated for inclusion in the study. The preoperative assessments of all patients had been performed routinely and included upper GI endoscopy, colonoscopy, histopathological analyses, upper abdominal tomography, pelvic magnetic resonance imaging, gynecological examination, and genetic studies, when and where necessary. The sociodemographic characteristics of the patients, surgical indications, the type of operation (one, two, or three stages), and histopathological diagnoses were obtained from medical records. Additionally, the early $(<3$ months) and late ( $\geq 3$ months) post-operative complications, including anastomotic stenosis, obstruction, pelvic sepsis, pouchitis, post-operative bleeding, wound infection, pouch failure, anastomotic leakage and fistula formation, were examined. The Cleveland Global Quality of Life (CGQL) score, used to evaluate quality of life, was completed by all patients, either by telephone interview or by e-mail. ${ }^{5}$

\section{Measures}

Sociodemographic Data Form was prepared by the authors to obtain demographic characteristics of interest including age, gender, body mass index (BMI), and so on. In addition, information about functional outcomes, such as the number of daily defecations, fecal incontinence, use of pads, presence of urinary and sexual dysfunction, anti-diarrheal drug use and postoperative pregnancy history was collected using this form.

The CGQL questionnaire is comprised of three dimensions: current quality of life; health status; and energy status. Each parameter is scored on a scale of 0 (worst outcome) to 10 (best outcome). The cumulative score obtained by the sum of the scores from all three parameters is divided by 30 to obtain the final CGQL score. $^{5}$

\section{Statistical Analysis}

All statistical analyses were performed using the Statistical Package for the Social Sciences (SPSS) version 22.0 (IBM Inc., Armonk, NY, USA). For descriptive analyses, categorical variables were reported as numbers (n) and percentages, and continuous variables are presented as mean \pm standard deviation or median (minimum-maximum) values depending on normality of distribution. The independent samples t-test was used for the comparison of variables demonstrating normal distribution, and the MannWhitney U test was used for the comparison of non-normally distributed variables. Chi-square tests were used to compare the distributions of categorical variables. Significance level was set at $\mathrm{p}<0.05$.

\section{Results}

Among the 26 individuals who had undergone IPAA during the study period, 22 patients ( 14 females and 8 males) were included in the analyses. Four patients were excluded for the following reasons. Two patients, one with FAP and the other operated because of UC but who actually had a colon tumor, died during their follow-up due to the reasons not related to the operation. In one other patient operated for UC, abdominoperineal resection was performed due to anastomotic recurrence. In the remaining patient operated for FAP, ileostomy closure was not performed due to the development of pouch fistula.

In the remaining 22 patients included in the analysis, all procedures were performed as open surgeries. At the time of their respective surgeries, median (range) age was 39 (20-71) years and the median BMI was 26.5 (19.2229.3) $\mathrm{kg} / \mathrm{m}^{2}$. Ten of the patients had UC and 12 had FAP (Table 1). Postoperative histopathological results indicated adenocarcinoma in two patients with UC and in four patients 
with FAP. A two-stage surgical procedure (ileostomy closure after IPAA) was performed in 19 (86.4\%) patients, and a three-stage surgical procedure (complete colectomy + RP complementary to ileostomy, followed by ileostomy closure) was performed on three (13.6\%) patients. All threestage surgeries were performed on patients with a diagnosis of UC. After proctocolectomy with total mesorectal excision in all patients, a J-pouch of $12-13 \mathrm{~cm}$ was formed with a stapler, and IPAA was performed with a $25 \mathrm{~mm}$ circular stapler. The median duration of ileostomy closure after the procedure was 3.5 (2-15) months. While the mean duration of ileostomy closure in patients with UC was 4.5 (3-15) months, it was $3(2-5)$ months in patients with FAP. The mean postoperative follow-up period of the patients was 44 (12-120) months. Before ileostomy closure, the pouch was evaluated using endoscopic and imaging methods.

In the early postoperative period, four (18.2\%) had ileus, five $(22.7 \%)$ had wound infections, three (13.6\%) had pelvic abscess, and other complications, such as deep vein thrombosis, urinary tract infection and pneumonia, developed in five (22.7\%). In the late postoperative period, two (9.1\%) developed pouchitis, two (9.1\%) developed anastomotic stenosis, and two (9.1\%) had pouch dysfunction.

\section{The Effect of the Final Diagnosis on the Complications (Table 2, 3)}

One of the patients with pouchitis had been diagnosed with UC and the other with FAP ( $10 \%$ versus $8.3 \%, \mathrm{p}=0.892$ ). Anastomotic stenosis was observed in one patient $(10 \%$ versus $8.3 \%$ ). Crohn's disease developed in one patient during follow-up. The patient was excluded from the study since the ileostomy closure had not yet been performed due to the development of pelvic abscess and pouch-vaginal fistula. Three patients with UC and one patient with FAP had ileus (30\% versus $8.3 \%$ ). A pelvic abscess was observed in three patients with UC; however, this was not observed in patients with FAP (30\% versus 0\%). Pouch dysfunction was observed in one patient in each diagnostic group (10\% versus $8.3 \%$ ). Wound infection was observed in three patients with UC and two patients with FAP (30\% versus $16.6 \%)$. In four patients with UC, complications such as DVT, urinary infection, and pneumonia were observed,

Table 1. Demographic characteristics according to diagnoses

\begin{tabular}{|c|c|c|c|c|}
\hline & $\mathrm{n}=22$ & $\begin{array}{l}\mathrm{UC} \\
\mathrm{n}=10\end{array}$ & $\begin{array}{l}\text { FAP } \\
n=12\end{array}$ & $\mathrm{P}$ \\
\hline Median (range) age, (years) & $39(20-71)$ & $37.5(28-71)$ & $39.5(20-59)$ & $0.229^{1}$ \\
\hline Gender (F/M) & $14 / 8$ & $6 / 4$ & $8 / 4$ & $0.746^{2}$ \\
\hline Median (range) BMI, $\left(\mathrm{kg} / \mathrm{m}^{2}\right)$ & $26.5(19.22-29.3)$ & $27.9(19.4-29.3)$ & $25.4(19.2-33.3)$ & $0.611^{1}$ \\
\hline Median (range) ileostomy closure time, (months) & $3.5(2-15)$ & $4.5(3-15)$ & $3(2-5)$ & $0.052^{1}$ \\
\hline Surgery type (two-/three-stage) & $19 / 3$ & $7 / 3$ & $12 / 0$ & $0.043^{1}$ \\
\hline Median (range) follow-up time (months) & $44(12-120)$ & $39(15-120)$ & $48.5(12-105)$ & $0.878^{1}$ \\
\hline
\end{tabular}

UC: Ulcerative colitis, FAP: Familial adenomatous polyposis, ${ }^{1}$ : Student t-test, ${ }^{2}$ : Pearson chi-square test, F: Female, M: Male

Table 2. Distribution of complications by diagnosis

$\begin{array}{llll}\text { Complications } & \mathbf{n}(\%) & \text { UC } & \text { FAP } \\ \mathbf{n}=10 & 1(10) & \mathbf{n}=12 \\ \text { Pouchitis } & 2(9.1) & 1(8.3) & 1(8.3) \\ \text { Anastomotic stricture } & 2(9.1) & - & - \\ \text { Pouch fistula } & - & - & - \\ \text { Anastomotic leak } & - & 3(30) & 1(8.3) \\ \text { Ileus } & 4(18.2) & 3(30) & - \\ \text { Pelvic abscess } & 3(13.6) & 1(10) & 1(8.3) \\ \text { Pouch dysfunction } & 2(9.1) & 3(30) & 2(16.6) \\ \text { Wound infection } & 5(22.7) & 4(40) & 1(8.3)\end{array}$

UC: Ulcerative colitis, FAP: Familial adenomatous polyposis 
whereas only one patient with FAP had a urinary infection (40\% versus $8.3 \%$ ).

\section{Functional Outcomes and Quality of Life}

Fecal incontinence was present in six (27.3\%) of the patients and four (18.2\%) of these used pads during the day. The mean frequency of defecation was $4.31 \pm 2.37$ times during the day and $1.04 \pm 0.89$ times during the night. Half of the patients $(50 \%)$ had complaints of sexual dysfunction. Two patients $(9.1 \%)$ were using anti-diarrheal drugs. One patient (7.14\%) conceived twice after the operation and gave birth by cesarean section in both cases.

\section{The Effects of Final Diagnosis on Functional Outcomes and Quality of Life}

Quality of life, as measured by the CGQL, was found to be significantly better in patients with FAP $(0.85 \pm 0.13)$ compared to those with UC $(0.71 \pm 0.11)$. There was no significant difference between the two groups in terms of other results.

\section{Discussion}

The colon and rectum are completely resected with RP and IPAA, ensuring the intestinal continuity of the patients and defecation via the anus. ${ }^{1}$ Utsunomiya et al. ${ }^{6}$ first described this procedure in 1978 as the manual anastomosis of an S-shaped pouch to the dentate line level after mucosectomy was performed in the remaining rectum. Over the years, J-, W-, and K-shaped pouch designs were also defined. Since the 1980s, the J-pouch and stapler anastomosis have become the most common techniques with the development and advances in surgical stapler technology. It has a simple design, the construction with the linear stapler is easier compared to the other techniques, and the application time is shorter. ${ }^{7}$ The IPAA procedure has various complications, including postoperative anastomotic leak, stricture, fistula, pelvic abscess, obstruction and pouchitis. Additionally, there are various postoperative consequences that negatively affect daily life activities and quality of life, such as an increase in the number of defecations during the day and at night, the urgent need to urinate, excessive weight loss, and fecal and gas incontinence.

In the present study, we evaluated the postoperative functional outcomes, complications, approaches to complications, and quality of life in patients who underwent IPAA in our clinic. The results of this procedure have been discussed since Utsunomiya et al. ${ }^{6}$ presented their initial IPAA results in 1978. According to previous studies, morbidity rates after IPAA vary between 30-60\%. $8,9,10,11$ However, surgical techniques are constantly changing and improving to reduce these morbidity rates. We used total mesorectal excision and $\mathrm{J}$ pouch stapler anastomosis technique in all our patients. In many studies, the J pouch has been reported as the most commonly preferred pouch type due to ease of application and good long-term functional outcomes. ${ }^{12,13,14}$ Studies comparing stapled anastomosis with hand-sewn anastomosis concluded that the functional outcomes were observed to be better with stapling. ${ }^{12,15}$ Considering the functional outcomes of the patients, we avoided mucosectomy in patients with no suspicion of dysplasia and neoplasia in the anal canal. ${ }^{16}$

The most common complications we encountered in our study were wound infection, pouchitis, anastomotic stenosis, pelvic abscess and pouch dysfunction. Fazio et al. ${ }^{5}$ demonstrated that such complications affected functional outcomes and the quality of life of patients. ${ }^{17}$ Tiainen and Matikainen ${ }^{18}$ reported that pouchitis was the most common

Table 3. Quality of life and functional results of patients according to diagnosis

\begin{tabular}{|c|c|c|c|c|}
\hline & $\mathrm{n}=22$ & $\begin{array}{l}\text { UC } \\
n=10\end{array}$ & $\begin{array}{l}\text { FAP } \\
n=12\end{array}$ & $\mathrm{P}$ \\
\hline Mean \pm SD CGQL score & $0.78 \pm 0.13$ & $0.71 \pm 0.11$ & $0.85 \pm 0.13$ & $0.015^{1}$ \\
\hline Mean \pm SD defecation episodes daytime & $4.31 \pm 2.37$ & $3.6 \pm 1.26$ & $4.91 \pm 2.93$ & $0.203^{1}$ \\
\hline Mean \pm SD defecation episodes at night & $1.04 \pm 0,89$ & $1.2 \pm 0.78$ & $0.91 \pm 0.99$ & $0.475^{1}$ \\
\hline Incontinence, $\mathrm{n}(\%)$ & $6(27.3)$ & $4(40)$ & $2(16.7)$ & $0.221^{2}$ \\
\hline Pad usage, n (\%) & $4(18.2)$ & $3(30)$ & $1(8.3)$ & $0.190^{2}$ \\
\hline Urinary dysfunction, n (\%) & $1(4.5)$ & - & $1(8.3)$ & $0.350^{2}$ \\
\hline Sexual dysfunction, n (\%) & $11(50)$ & $6(60)$ & $5(41.7)$ & $0.392^{2}$ \\
\hline Anti-diarretic drug use, n (\%) & $2(9.1)$ & $1(10)$ & $1(8.3)$ & $0.892^{2}$ \\
\hline Pregnancy, n (\%) & $1(4.5)$ & $1(10)$ & - & $0.262^{2}$ \\
\hline
\end{tabular}

UC: Ulcerative colitis, FAP: Familial adenomatous polyposis, CGQL= Cleveland global quality of life; SD: Standard deviation; $\mathrm{p}<0.05$ as determined by ${ }^{1}$ : Student t-test, ${ }^{2}$ : Pearson chi-square test, All data represented as $\mathrm{n}, \%$ or mean \pm standard deviation 
complication after IPAA. Similar to our study, certain studies reported that small bowel obstruction was one of the most common complications of RP and is encountered in $12-17 \%$ of all patients. ${ }^{19,20,21}$ When we compared patients with UC and FAP, the development of ileus and pelvic abscess in patients with UC was significantly more frequent compared to the patients with FAP. This finding is supported by a study by Fazio et al..$^{22}$ that reported increased frequency of many complications in patients with UC.

Despite previous studies concluding that protective ileostomy would not prevent pelvic sepsis ${ }^{23}$ or anastomotic leaks ${ }^{24,25}$ after IPAA, we performed protective ileostomy in all of our patients and closed the ileostomies, after controlling via endoscopy and pouch radiography, at an average of 4.2 months. When we identified problems such as pouch fistula and pouchitis on endoscopy and pouch radiography, we postponed the ileostomy closure procedure and initiated treatment when necessary.

We performed two-stage RP surgery in all patients diagnosed with FAP and those with UC, while three-stage surgery was performed in patients with acute, severe colitis who had received an extended period of steroid therapy or anti-tumor necrosis factor (TNF) therapy. ${ }^{12,26}$

Patients who undergo IPAA are expected to have defecations 4-6 times during the day and 0-1 times at night, with complete continence. ${ }^{27,28}$ The number of day and night defecations were compatible with the literature in our patients. However, six patients had fecal incontinence, two of whom needed to use pads. These outcomes were found to be acceptable and in agreement with prior studies. ${ }^{29}$

Gklavas et al. ${ }^{30}$ reported that proctocolectomy in patients with inflammatory bowel disease caused no adverse effects on sexual function. These authors highlighted that all surgery in their report had been performed by an experienced colorectal surgeon. They also highlighted the importance of the surgical technique and the fact that it was crucial to spare the nerve plexi within the pre-sacral region. ${ }^{30}$ In contrast, Harnoy et al. ${ }^{31}$ observed worsening of sexual function in up to $50 \%$ of women, while erectile dysfunction was identified in $25 \%$ of men after RP with IPAA. In our study, half of the patients stated that they suffered from sexual dysfunction. Of note, one of our patients conceived twice after the operation.

With respect to quality of life evaluation, our patients were satisfied with the IPAA operation and the CGQL scores indicated similar quality of life to that reported by Ozdemir et al. ${ }^{1}$ When the UC and FAP groups were compared, it was seen that the results of patients with FAP were better in terms of complications, functional outcomes, and quality of life score. The worse functional outcomes for UC compared with FAP may be because UC patients required emergency surgery for fulminant colitis, underwent preoperative medical treatments and suffered from malnutrition during the preoperative period.

The IPAA procedure was associated with a certain complication rate, as well as functional outcomes and results affecting the quality of life. However, these were at an acceptable level when compared to the preoperative period. In a study by Lichtenstein et al. ${ }^{32}$, which examined 10 clinical studies assessing quality of life after IPAA, quality of life was found to have increased in $80 \%$ of the studies, remained the same in one of the studies, and was worse compared to the general population included in the remaining study.

\section{Study Limitations}

The insufficient number of patients and the retrospective nature of the study are the most important limitations. However, postoperative complication rates, functional outcomes and quality of life of the patients were similar when compared to the literature.

\section{Conclusion}

In conclusion, our experience with the IPAA procedure demonstrates that this procedure can be applied safely with low comorbidity and good functional outcomes. We believe that this is partly dependent on sufficient caseload, producing experienced clinicians, which will tend to minimize the post-operative complication rate and improve quality of life.

\section{Ethic}

Ethics Committee Approval: Gazi University Faculty of Medicine, 24074710-06, 10.02.2020

Informed Consent: Informed consent was obtained from all individual participants included in the study.

\section{Author Contributions}

Concept: A.Y., O.Y., Design: A.Y., Data Collection and/or Processing: H.G., O.K., S.A., Analysis and/or Interpretation: K.D., H.B., Literature Search: A.Y., Writing: A.Y. Critical Review: K.D., O.Y.

Conflict of Interest: The authors have no conflict of interest to declare.

Financial Disclosure: The authors declared that this study has received no financial support.

\section{References}

1. Ozdemir Y, Kiran RP, Erem HH, Aytac E, Gorgun E, Magnuson D, Remzi FH Functional outcomes and complications after restorative proctocolectomy and ileal pouch anal anastomosis in the pediatric population. J Am Coll Surg 2014;218:328-335. 
2. Griffiths AM. Inflammatory bowel disease. Nutrition (Burbank, Los Angeles County, Calif) 1998;14:788-791.

3. Groden J, Thliveris A, Samowitz W, Carlson M, Gelbert L, Albertsen H, Joslyn G, Stevens J, Spirip L, Robertson M. Identification and characterization of the familial adenomatous polyposis coli gene. Cell 1991;66:589-600.

4. Bussey H, editor Familial polyposis coli : family studies, histopathology, differential diagnosis, and results of treatment 1975.

5. Fazio VW, O'Riordain MG, Lavery IC, Church JM, Lau P, Strong SA, Hull T. Long-term functional outcome and quality of life after stapled restorative proctocolectomy. Ann Surg 1999;230:575-584; discussion 84-86.

6. Utsunomiya J, Iwama T, Imajo M, Matsuo S, Sawai S, Yaegashi K, Hirayama R. Total colectomy, mucosal proctectomy, and ileoanal anastomosis. Dis Colon Rectum 1980;23:459-466.

7. Simillis C, Afxentiou T, Pellino G, Kontovounisios C, Rasheed S, Faiz $\mathrm{O}$, Tekkis P. A systematic review and meta-analysis comparing adverse events and functional outcomes of different pouch designs after restorative proctocolectomy. Colorectal Dis 2018;20:664-675.

8. Alexander F. Complications of ileal pouch anal anastomosis. Semin Pediatr Surg 2007;16:200-204.

9. Efron JE, Uriburu JP, Wexner SD, Pikarsky A, Hamel C, Weiss EG, Nogueras JJ. Restorative Proctocolectomy with Ileal Pouch Anal Anastomosis in Obese Patients. Obes Surg 2001;11:246-251.

10. Kiran RP, Remzi FH, Fazio VW, Lavery IC, Church JM, Strong SA, Hull TL. Complications and functional results after ileoanal pouch formation in obese patients. J Gastrointest Surg 2008;12:668-674.

11. Sup SU, Sik YC, Dong KD, Nam YS, Cheon KJ. Risk Factors of Pouch Failure after a Restorative Proctocolectomy. J Korean Soc Coloproctol 2008;24:252-259

12. Øresland T, Bemelman WA, Sampietro GM, Spinelli A, Windsor A, Ferrante M, Marteau P, Zmora O, Kotze PG, Espin-Basany E, Tiret E, Sica G, Panis Y, Faerden AE, Biancone L, Angriman I, Serclova Z, de Buck van Overstraeten A, Gionchetti P, Stassen L, Warusavitarne J, Adamina M, Dignass A, Eliakim R, Magro F, DiHoore A. European evidence based consensus on surgery for ulcerative colitis. J Crohn's Ccolitis 2015;9:4-25.

13. Remzi FH, Lavryk OA, Ashburn JH, Hull TL, Lavery IC, Dietz DW, Kessler H, Church JM. Restorative proctocolectomy: an example of how surgery evolves in response to paradigm shifts in care. Colorectal Dis 2017;19:1003-1012.

14. Lovegrove RE, Heriot AG, Constantinides V, Tilney HS, Darzi AW, Fazio VW, Nicholls RJ, Tekkis PP. Meta-analysis of short-term and long-term outcomes of J, W and S ileal reservoirs for restorative proctocolectomy. Colorectal Dis 2007;9:310-320.

15. Lovegrove RE, Constantinides VA, Heriot AG, Athanasiou T, Darzi A, Remzi FH, Nicholls RJ, Fazio VW, Tekkis PP. A comparison of hand-sewn versus stapled ileal pouch anal anastomosis (IPAA) following proctocolectomy: a meta-analysis of 4183 patients. Ann Surg 2006;244:18-26.

16. Chambers WM, Mc CMNJ. Should ileal pouch-anal anastomosis include mucosectomy? Colorectal Dis 2007;9:384-892.

17. Fazio VW, Ziv Y, Church JM, Oakley JR, Lavery IC, Milsom JW, Schroeder TK.Ileal pouch-anal anastomoses complications and function in 1005 patients. Ann Surg 1995;222:120-127.
18. Tiainen J, Matikainen M. Health-related quality of life after ileal J-pouchanal anastomosis for ulcerative colitis: long-term results. Scand J Gastroenterol 1999;34:601-605.

19. Dolejs S, Kennedy G, Heise CP. Small bowel obstruction following restorative proctocolectomy: affected by a laparoscopic approach? J Surg Res 2011;170:202-208.

20. Fichera A, Silvestri MT, Hurst RD, Rubin MA, Michelassi F. Laparoscopic restorative proctocolectomy with ileal pouch anal anastomosis: a comparative observational study on long-term functional results. J Gastrointest Surg. 2009;13:526-532.

21. Pandey S, Luther G, Umanskiy K, Malhotra G, Rubin MA, Hurst RD, Fichera A.Minimally invasive pouch surgery for ulcerative colitis: is there a benefit in staging? Dis Colon Rectum 2011;54:306-310.

22. Fazio VW, Kiran RP, Remzi FH, Coffey JC, Heneghan HM, Kirat HT, Manilich E, Shen B, Martin ST. Ileal pouch anal anastomosis: analysis of outcome and quality of life in 3707 patients. Ann Surg 2013;257:679-685.

23. Kiran RP, da Luz Moreira A, Remzi FH, Church JM, Lavery I, Hammel J, Fazio VW. Factors associated with septic complications after restorative proctocolectomy. Ann Surg 2010;251:436-440.

24. Platell C, Barwood N, Makin G. Clinical utility of a de-functioning loop ileostomy. ANZ J Surg 2005;75:147-151.

25. Wong NY, Eu KW. A defunctioning ileostomy does not prevent clinical anastomotic leak after a low anterior resection: a prospective, comparative study. Dis Colon Rectum 2005;48:2076-2079.

26. Magro F, Gionchetti P, Eliakim R, Ardizzone S, Armuzzi A, Barreiro-de Acosta M, Burisch J, Gecse KB, Hart AL, Hindryckx P, Langner C, Limdi JK, Pellino G, Zagórowicz E, Raine T, Harbord M, Rieder F. Third European Evidence-based Consensus on Diagnosis and Management of Ulcerative Colitis. Part 1: Definitions, Diagnosis, Extra-intestinal Manifestations, Pregnancy, Cancer Surveillance, Surgery, and Ileo-anal Pouch Disorders. J Crohn's Colitis 2017;11:649-670.

27. Pakarinen MP, Natunen J, Ashorn M, Koivusalo A, Turunen P, Rintala RJ, Kolho KL. Long-term outcomes of restorative proctocolectomy in children with ulcerative colitis. Pediatrics 2009;123:1377-1382.

28. Wewer V, Hesselfeldt P, Qvist N, Husby S, Paerregaard A. J-pouch ileoanal anastomosis in children and adolescents with ulcerative colitis: functional outcome, satisfaction and impact on social life. J Pediatr Gastroenterol Nutr 2005; 40:189-193

29. McIntyre PB, Pemberton JH, Beart RW Jr, Devine RM, Nivatvongs S. Double-stapled vs. handsewn ileal pouch-anal anastomosis in patients with chronic ulcerative colitis. Dis Colon Rectum 1994:37:430-433.

30. Gklavas A, Kyprianou C, Exarchos G, Metaxa L, Dellis A, Papaconstantinou I. Sexual function after proctectomy in patients with inflammatory bowel disease: A prospective study. Turk J Gastroenterol 2019;30:943-950.

31. Harnoy Y, Desfourneaux V, Bouguen G, Rayar M, Meunier B, Siproudhis L, Boudjema K, Sulpice L. Sexuality and fertility outcomes after hand sewn versus stapled ileal pouch anal anastomosis for ulcerative colitis. J Surgical Res 2016;200:66-72.

32. Lichtenstein GR, Cohen R, Yamashita B, Diamond RH. Quality of life after proctocolectomy with ileoanal anastomosis for patients with ulcerative colitis. J Clin Gastroenterol 2006;40:669-677. 